\title{
INTERRELASI ANTARA ETIKA DAN SISTEM EKONOMI (Studi Pemikiran Ekonomi Ibnu Khaldun)
}

\author{
Abdul Salam \\ (Dosen Ekonomi Syariah STIA Alma Ata Yogyakarta)
}

\begin{abstract}
Ibn Khaldun was one of the scholars' greatest that no one doubted his dept of knowledge of Islamic religion. In the Islamic religious knowledge, he has trained by many greatest scholars since childhood moment-one of them is his father. Ibn Khaldun can also be called as a scientist who never ask and doubted the truth of Islamic law. Understanding that any observations for him, he could not be separated from the Islamic values inherent in him. Through in-depth discussion and critical of his work, will be seen in ethical view of religious that accommodate economic teachings of Islam, and other hand the human family to recognize the nature to endeavor economic activity.

This type of research is the research library (library research), to describe something. Data collection techniques using qualitative methods as the research procedures to descriptive data. To analyze the data that was gathered using the deductive, using a philosophical approach.

Historically there is close relationship between ethics and economics, which was originally it was part of the problem of economic ethics. Ibn Khaldun's economic notion explain a multidimensional economic concepts that involving various social aspects in the context of his thinking about the al-al-basyari'amran which describes the rise and fall of a civilization which moral decline influence in it. Ibn Khaldun's economic concept implies an economic system that requires the five components, namely Shari'ah, government, people, property, economic activity and justice, in unity.

Keywords: Interrelation, ethical, economic systems, Ibn Khaldun
\end{abstract}

\section{A. Latar Belakang}

Kritik pedas yang dilontarkan para ahli ekonomi dan sosial terhadap sistem ekonomi kapitalisme dewasa ini adalah kian kaburnya nilai-nilai yang melandasi munculnya sistem tersebut. Kapitalisme yang sering dinisbahkan kepada Adam Smith yang mendasarkan pemikiran sosial-ekonominya pada etika hukum alam dengan mengajukan konsep pasar bebas, dalam perkembangannya, sangat mengedepankan corak individualistis (self interest) hingga merenggangkan kerekatan sosial masyarakat dan menampakkan kecenderungan untuk meninggalkan nilai-nilai etika yang ada di dalamnya. Bahkan lebih itu, menurut Max Weber, jika semula kapitalisme tumbuh dan berkembang karena menggunakan prinsip etika Protestan, maka kemudian- karena adanya pergantian prinsip tersebut-kapitalisme dengan cepat menghacurkan agama beserta nilai-nilai ajarannya. bendera sosialisme. Pemikiran revolusioner Marx tersebut selain mengkritik proses dehumanisasi pada sistem ekonomi kapilisme, juga menawarkan beberapa "program kerja" sistem ekonomi sosialis, antara lain : pengahpusan hak milik pribadi atas alat-alat produksi, penghapusan kelas-kelas social, menghilangnya 
Negara dan pengahapusan pembagian kerja. Di sini kesan yang paling menonjol adalah pengabaian terhadap nilai-nilai kebebasan individual manusia, meskipun Marx berangkat dari kritik keterasingan manusia dalam sistem kapitalisme dalam melakukan aktivitas-aktivitas ekonomi. Hasilnya, sampai saat ini sosialisme belum mampu betul-betul membumikan idenya pada masyarakat global.

Kapitalisme mendapat kecaman karena kian lunturnya nilai-nilai etis yang semula melahirkan dan sosialisme hanya berjalan ditempat karena salah satunya mengabaikan nilai-nilai kebebasan individual manusia. Satu hal yang bisa kita kemukakan berkaitan dengan hal ini adalah bahwa suatu sistem ekonomi harus ditopang oleh nilai-nilai etis yang menjunjung harkat manusia dan nilai-nilai yang telah tertanam dalam diri manusia sebagai makhluk ekonomi (homo economicus). Jadi, pokok permasalahannya terletak pada nilai-nilai dan buruk yang dijadikan sebagai dasar pandangan hidup atau yang lebih tegasnya dapat disebut etika. Dalam membuat keputusan yang berkaitan dengan ekonomi, nilai etika sepatutnya dijadikan sebagai norma.

Wacana ekonomi Islam yang muncul belakangan, setelah kapitalisme dam sosialisme tampak sangat mengedepankan sisi etika yang disandarkan pada ajaran Islam. Bahkan juga dikatakan bahwa sisi etika inilah yang membedakan sistem ekonomi Islam dari sistem ekonomi lainnya. Etika yang dimaksud di sini tentu saja adalah etika yang diambil dari ajaran agama Islam di mana setiap agama pasti memberikan pedoman-pedoman etika pada para pemeluknya. M. Abdul Mannan mendefinisikan ilmu ekonomi Islam sebagai ilmu pengetahuan social yang mempelajari masalah-masalah ekonomi rakyat yang diilhami oleh nilai-nilai Islam. Dengan perangkat etika ini sistem ekonomi Islam diyakini mampu mengatasi berbagai macam krisis yang muncul berkaitan dengan permasalahan ekonomi. Masalahnya kemudian adalah bagaimana format sintesa yang tepat antara etika dan sistem ekonomi sehingga satu sama lain saling mendukung? Apakah sistemnya yang akan mengarahkan bentuk etika yang diterpkan, dalam hal ini sistem ekonomi yang berlaku dijadikan alat untuk "menafsirkan" ajaran-ajaran Islam ? ataukah etika yang akan menjadi panglima dalam setiap pengambilan kebijakan ekonomi?

Dalam tulisan ini penyusun mengajukan pemikiran Ibnu Khaldun (1332 1406 M) untuk di antaranya menjawab pertanyaan-pertanyaan tersebut. Pemikiran ekonomi Ibnu Khaldun sebagaimana yang tertuang dalam karyanya, alMiqaddimah, cukup relevan untuk dapat menjawab persoalan tersebut. Pemikiran ekonomi Ibnu Khaldun sangat terkait dengan obyek kajian utamanya alMuqaddimah, yaitu tentang al-'umran al-basyari (peradaban manusia). Dalam hal ini, Ibnu Khaldun sering sekali secara eksplisit maupun implicit mengkritik perilaku bermewah-mewahan suatu masyarakat yang telah maju sebagai titik balik merosotnya kehidupan ekonomi suatu masyarakat atau peradaban hingga menuju keruntuhannya. Dari konteks besar pemikirannya tersebut banyak teori-teori ekonomi yang dapat digali yang sebenarnya berpijak pada pengamatan empirisnya terhadap perilaku ekonomi berbagai masyarakat yang ditemuinya. Karena teori-teori ekonomi Ibnu Khaldun bisa dimasukkan ke dalam kategori ilmu ekonomi positif (positive economics) yang didasarkan pada pengamatan empiris dengan pendekatan sosiologis.

Secara garis besar perhatiannya pada masalah ekonomi bertolak dari adanya interrelasi dalam perekonomiannya secara makro antara beberapa komponen yaitu syari'at (agama), pemerintah, rakyat, harta (kondisi ekonomi), aktivitas ekonomi dan keadilan. Interrelasi yang dimaksudkan disini adalah lebih dari sekedar relasi adanya hubungan resiprokal antara komponen-komponen tersebut. Konsep dan interrelasi inilah yang akan menjadi fokus kajian dalam tulisan ini. Melalui konsep ekonomi yang disarikan dari pemikiran Ibnu khaldun, 
penyusun melakukan upaya menjelaskan interralasi antara etika da sistem ekoomi yang terjalin di dalamnya.

Mengenai Ibnu Khaldun sendiri, dia lebih tersohor sebagai seorang sejarawan dan sosiolog. Terlahir dan melalui masa hidup dalam suasana perpolitikan yang tidak menentu, dia juga tampil sebagai seorang negarawan yang handal. Tapi tidak sedikit pula yang mengakui dan mengapresiasi keahliannya dalam bidang ekonomi.

Terkait dengan ketokohannya yang menonjol di bidang sejarah dan sosiologi, untuk mempelajari pemikiran ekonomi ulama dari Tunisia itu mau tidak mau juga harus melibatkan kedua bidang tersebut. Sebagian beesar teori ekonomi yang dia kemukakan integral dengan pemikiran-pemikiran sosiologinya yang berangkat dari pengamatan historis. Ibnu khaldun sendiri memperlihatkan kesan itu dalam ungkapannya bahwa perbedaan hal ikhwal penduduk adalah akibat dari perbedaan cara mereka memperoleh penghidupan (cara-cara produksi). Ini berarti baginya ekonomi memiliki peran yang cukup besar dalam ikut menentukan arah perjalanan sejarah.

Di atas itu semua, yang tidak boleh dilupakan, Ibnu Khaldun adalah salah seorang ulama Islam terbesar yang kedalam pengetahuan agamanya tidak perlu diragukan lagi. Dalam bidang pengetahuan agama Islam, beliau sejak kecil telah digemleng oleh banyak ulama besar saat itu -salah satunya ayah beliau sendiri. Menurut Syathi al-Husri, dalam karyanya Dirasat 'an Muqaddimah Ibn Khaldun, sebagaimana dikutip Zainab al-Khudhairi, kandungan Muqaddimah menunjukkan secara jelas bahwa penyusunnya adalah seorang mukmin yang taat dan mempercayai Allah dan Islam secara mendalam. Ibn Khaldun dapat juga dikatakan sebagai seorang ilmuwan yang tidak pernah mempertanyakan dan meragukan kebenaran syari'at Islam. Dari sini dapat dimaklumi bahwa seempiris apapun hasil pengamatanya, tidak terlepas dari sentuhan nilai-nilai Islam yang melekat dalam dirinya. Melalui pembacaan secara mendalam dan kritis terhadap karyanya tersebut akan terlihat pandangan etis-religiusnya dalam bidang ekonomi yang mengakomodasi ajaran-ajaran Islam di satu sisi dan mengakui eksistensi "fitrah" manusia untuk melakukan aktivitas-aktivitas ekonomi di sisi lain

\section{B. Tinjauan Pustaka}

\section{a. Etika}

Menurut bahasa Yunani Kuno, etika berasal dari kata ethikos yang berarti "timbul dari kebiasaan". Etika adalah cabang utama filsafat yang mempelajari nilai atau kualitas yang menjadi studi mengenai standar dan penilaian moral. Etika mencakup analisis dan penerapan konsep seperti benar, salah, baik, buruk, dan tanggung jawab. Etika terbagi menjadi tiga bagian utama: meta-etika (studi konsep etika), etika normatif (studi penentuan nilai etika), dan etika terapan (studi penggunaan nilai-nilai etika) (id.wikipedia.org). Pengertian etika berbeda dengan etiket. Etiket berasal dari bahasa Prancis etiquette yang berarti tata cara pergaulan yang baik antara sesama menusia. Sementara itu etika, berasal dari bahasa Latin, berarti falsafah moral dan merupakan cara hidup yang benar dilihat dari sudut budaya, susila, dan agama. Etika merupakan filsafat / pemikiran kritis dan rasional mengenal nilai dan norma moral yg menentukan dan terwujud dalam sikap dan pada perilaku hidup manusia, baik secara pribadi maupun sebagai kelompok. (sebuah ilmu : pengejawantahan secara kritis ajaran moral yang dipakai).

Untuk menganalisis arti-arti etika, dibedakan menjadi dua jenis etika (Bertens, 2000):

1. Etika sebagai Praktis

Interrelasi

Antara a. Nilai-nilai dan norma-norma moral sejauh dipraktekkan atau justru tidak dipraktekkan walaupun seharusnya dipraktekkan. 
b. Apa yang dilakukan sejauh sesuai atau tidak sesuai dengan nilai dan norma moral.

2. Etika sebagai Refleksi

a. Pemikiran moral $\square$ berpikir tentang apa yang dilakukan dan khususnya tentang apa yang harus dilakukan atau tidak boleh dilakukan.

b. Berbicara tentang etika sebagai praksis atau mengambil praksis etis sebagai objeknya.

c. Menyoroti dan menilai baik buruknya perilaku orang.

d. Dapat dijalankan pada taraf populer maupun ilmiah.

b. Sistem Ekonomi

Sistem ekonomi adalah suatu proses yang menyebabkan pendapatan yang berdampak pada kehidupan masyarakat baik dalam jangka panjang maupun jangka pendek.

Dari definisi diatas memiliki beberapa sifat penting yaitu; i) suatu proses, yang merupakan perubahan yang terjadi secara terus menerus, ii) sesuatu yang dapat merubah tingkat penghidupan masyarakat.

Pendapat lain juga menegaskan bahwa sistem ekonomi adalah cara suatu bangsa atau negara dalam menjalankan perekonomianya. Secara umum sistem ekonomi di bagi menjadi 5 yaitu : Sistem ekonomi tradisional, sistem ekonomi terpusat, sistem ekonomi pasar dan sistem ekonomi campuran.

Sistem ekonomi yang diterapkan di Indonesia adalah sistem ekonomi pancasila yang disebut juga demokrasi ekonomi. Landasan pokoknya pasal 33 ayat 1-4 UUD 1945 (hasil amandemen). Adapun hal-hal yang harus dihindari dalam sistem demokrasi ekonomi, yaitu sistem free fight liberalism, sistem etatisme, dan monopoli.

Beberapa pendapat para ahli yang terkait dengan sistem ekonomi antara lain :

\section{Chester A Bemand mengatakan bahwa :}

"Sistem ekonomi adalah suatu kesatuan yang terpadu yang secara kolestik yang di dalamnya ada bagian-bagian dan masing-masing bagian itu memiliki ciri dan batas tersendir"

2. Dumatry (1996) mengatakan bahwa :

"Sistem ekonomi adalah suatu sistem yang mengatur serta menjalin hubungan ekonomi antar manusia dengan seperangkat kelembagaan dalam suatu ketahanan".

3. Gregory Grossman and M. Manu mengatakan bahwa :

"Sistem ekonomi adalah sekumpulan komponen-komponen atau unsurunsur yang terdiri dari atas unit-unit dan agen-agen ekonomi, serta lembagalembaga ekonomi yang bukan saja saling berhubungan dan berinteraksi melainkan juga sampai tingkat tertentu yang saling menopang dan mempengaruhi."

4. Menurut M. Hatta :

"Sistem ekonomi yang baik untuk diterapkan di Indonesia harus berdasarkan atas asas kekeluargaan"

Berdasarkan beberapa pendapat para ahli di atas dapat penulis simpulkan bahwa sistem ekonomi bukan hanya sebagai sekumpulan komponen atau unit perekonomian tetapi merupakan sebuah penerapan yang dikembangkan oleh seperangkat masyarakat yang masing-masing memiliki ciri dan batas-batas tersendiri.

\section{c. Macam-Macam Sistem Ekonomi}

Ada 4 macam sistem ekonomi di Indonesia, yang terdiri dari :

\section{Sistem ekonomi Tradisional}

Dalam sistem ekonomi tradisional kegiatan ekonomi masih menggunakan tradisi turun-temurun yang berlaku dalam suatu masyarakat dan telah menjadi nilai budaya setempat. Kegiatan produksi dalam sistem perekonomian tradisional

\section{Abdul \\ Salam}


dilakukan secara bergotongroyong dan bersifat kekeluargaan. Adapun ciri-ciri dari sistem ekonomi tradisional antara lain adalah sebagai berikut :

a. Kegiatan produksi umumnya mengolah ttanah dan mengumpulkan benda yang disediakan alam

b. Alat produksi masih sederhana

c. Sangat tergantung pada alam

d. Hasil produksi untuk kebutuhan minimal dan besifat homogen

e. Hasil industri berupa hasil kerajinan tangan

f. Belum mengenal tukar menukar secara kredit (Kardiman, $2006: 78$ ).

2. Sistem Ekonomi terpusat

Sistem ekonomi terpusat yang disebut juga sistem ekonomi sosialis adalah suatu sistem ekonomi dimana seluruh sumber daya dan pengolahannya direncanakan dan dikendalikan oleh pemerintah.

Dari uraian di atas dapat disimpulkan sistem ekonomi terpusat memiliki ciri-ciri sebagai berikut :

1. Seluruh sumber daya dikuasai oleh Negara

2. Produksi dilakukan untuk kebutuhan masyarakat

3. Kegiatan ekonomi direncanakan oleh negara dan diatur pemerintah secara terpusat

4. Hak milik individu tidak diakui (Kardiman, 2006 : 79)

\section{Sistem ekonomi liberal}

Sistem ekonomi liberat disebut juga ekonomi pasar, yaitu sistem ekonomi di mana pengelolaan ekonomi diatur oleh kekuatan pasar (permintaan dan penawaran). Sistem ekonomi ini menghendaki adanya kebebasan individu dalam melakukan kegiatan ekonomi. Artinya, setiap individu diakui keberadaanya dan mereka bebas bersaing.

Sejalan dengan uraian di atas berikut ciri-ciri sistem ekonomi pasar :

1. Adanya pengakuan terhadap hak individu

2. Setiap manusia adalah homo economicus

3. Kedaulatan konsumen dan kebebasan dalam konsumsi

4. Menerapkan sistem persaingan bebas

5. Motif mencari laba terpusat pada kepentingan sendiri

6. Peranan modal sangat penting

7. Peranan pemerintah dibatasi (Sardiman, $2006: 80$ ).

4. Sistem ekonomi campuran

Sistem ekonomi campuran adalah sistem ekonomi yang berusaha mengurangi kelemahan-kelemahan yang timbul dalam sistem ekonomi terpusat dan sistem ekonomi pasar. Dalam sistem ekonomi campuran pemerintah keberka sama dengan pihak swasta dalam menjalankan kegiatan perekonomian (Sardiman, $2006: 80)$

\section{Pembahasan}

a. Konsep Ekonomi Ibnu Khaldun

Apa yang kemudian penyusun ketengahkan di sini adalah konsep ekonomi yang terbangun dari pemikiran sosio-ekonomi Ibnu khaldun Konsep yang dimaksudkan di sini adalah suatu pemikiran yang umum atau suatu ide yang diabstrakkan melalui peristiwa nyata (a general or abstract idea). Sehingga, sekali lagi, apa yang ditengahkan di sini bukanlah suatu "ilmu ekonomi", akan tetapi suatu pemikiran umum tentang ekonomi yang dalam hal ini adalah

Interrelasi pemikiran ekonomi Ibnu Khaldun dalam pengertian konsep tersebut.

Antara

Secara garis besar pemikiran ekonomi Ibnu Khaldun dapat disistematikan bahwa titik tolak pemikiran ekonomi Ibnu Khaldun dapat dilihat dari 
pernyataannya bahwa perbedaan hal ihwal penduduk adalah akibat dari perbedaan cara mereka memperoleh kehidupan. Dalam ilmu sejarah, apa yang dikemukakan Ibnu khaldun tersebut memperlihatkan signifikansi ekonomi bagi perkembangan sejarah. Hal ini terlihat lebih jelas dengan pernyataannya bahwa manusia hidup bermasyarakat hanyalah untuk saling membantu di dalam memperoleh penghidupan dan untuk membantu kebutuhan hidup yang sederhana sebelum mereka mencari kebutuhan yang lebih tinggi.

Kemudian apa yang dikemukakan Ibnu Khaldun tersebut dapat dijelaskan dengan pembahasannya tentang berbagai aspek yang berkaitan dengan pencarian penghidupan (al-ma'asy) yang dilakukan manusia (pada bab V dari alMuqaddimah). Ibnu Khaldun menjelaskan bahwa manusia menurut kodratnya memang membutuhkan makanan serta berusaha memenuhi kebutuhan hidupnya dan dalam hal ini Allah telah menciptakan segala sesuatu yang terdapat di dunia ini untuk manusia.

Kemudian, menurut Ibnu Khaldun keberadaan manusia di bumi adalah sebagai khalifah Allah untuk 'mengusai" semua yang ada di bumi. Tiap manusia memiliki hak terhadap apa yang ada di bumi ini. Tapi ketika seseorang telah memiliki barang dengan usahanya maka orang lain tidak boleh mengambilnya kecuali melalui pertukaran yang senilai. Di sinilah kemudian Ibnu Khaldun menekankan pentingnya seseorang untuk berusaha mendapatkan penghasilan dari apa yang telah disediakan Tuhan untuk kemudian dapat memperdagangkannya (melalui pertukaran) guna memenuhi kebutuhannya. Dengan usaha tersebut seseorang bisa memperoleh keuntungan yang apabila dapat digunakan untuk memenuhi kebutuhannya, maka itulah yang disebut rezeki dan bila masih ada kelebihan dapat menjadi modal untuk memperoleh penghidupan. Dalam hal ini Ibnu Khaldun sangat menekankan arti penting usaha yang dilakukan manusia untuk dapat memperoleh keuntungan atau pendapatan. Memang hasil yang akan diperoleh adalah bergantung pada Allah karena segala sesuatu adalah berasal dari Allah dan bahkan menurutnya keuntungan bisa saja datang tanpa melalui usaha sebagimana hujan yang menumbuhkan tanaman. Tetapi sekalipun begitu, alam yang diciptakan Allah hanyalah bertindak sebagai pembantu yang tidak bisa berbuat apa-apa bila manusia tidak bekerjasama dengannya melalui usaha dan kerja. Kerja manusia merupakan suatu keharusan di dalam setiap keuntungan dan penumpukan modal, maka rezeki haruslah dengan usaha dan kerja meski cara memperoleh dan mengusahakannya dilakukan dengan berbagai cara. Hal ini dicontohkan dengan usaha pertukangan, pertanian, ataupun peternakan yang apabila tanpa usaha maka idak akan memperoleh hasil atau keuntungan. Hasil ataupun modal yang diperoleh melalui usaha semacam itu merupakan nilai yang terealisasi dari kerja.

Berangkat dari konsep nilai kerja tersebut, Ibnu Khaldun mengemukakan bahwa biaya produksi suatu barang harus mencakup nilai kerja karena tidak akan ada produksi bila tidak ada kerja. Bahkan dia mengatakan bahwa suatu produksi, harga bahan mentah memang harus diperhitungkan, tetapi apabila "kerja" mengambil bagian yang banyak dalam produksi tersebut, nilai kerja harus lebih tinggi dari bahan mentah. Selain itu Ibnu Khaldun juga memaparkan berbagai bentuk usaha unuk memperoleh penghidupan seperti beternak, bertani, menjahit, memenun, industri, perdagangan dan lain sebagainya yang mencakup produksi barang maupun jasa.

Selanjutnya, sekelumit penjelasan dari konsep ekonomi Ibnu Khaldun merupakan bagian dari konsep sistem sosio-ekonomi yang lebih besar lagi yang melibatkan negara (daulah) beserta komponen-komponennya. Di sinilah konteks al'umran al-basyari (peradaban manusia) secara makro menjadi bagian tak terpisahkan dari konsep ekonomi Ibnu Khaldun. Secara garis besar konsep ekonomi Ibnu Khaldun yang tercakup dalam kajian 'umran-nya memiliki

Abdul
Salam 
kemiripan dengan konsep materialisme historis dari Karl Max yang intinya menyatakan bahwa perkembangan sejarah manusia sangat dipengaruhi oleh mode produksi mereka, sebagaimana yang dikutip Erich Fromm dalam bukunya. Selain itu, konsep ekonomi Ibnu Khaldun juga memiliki kemiripan ekonomi Adam Smith yang mempopulerkan teori mekanisme pasar dalam konsep sistem pasar bebasnya ketika dia menyatakan bahwa rakyat harus dibebaskan dari kekangan dan terutama kezaliman penguasa dalam kegiatan ekonomi yang dapat menyebabkan lemahnya kondisi ekonomi hingga kemudian hancurnya peradaban. Bahkan Ibnu Khaldun juga menyatakan bahwa perdagangan yang dilakukan raja (penguasa) akan membahayakan rakyat karena pada gilirannya raja akan menggunakan kekuasaan untuk kepentingan perdagangannya hingga merusak harga pasar. Namun begitu Ibnu Khaldun tetap memandang perlunya penguasa (pemerintah) menjadi penjamin berlangsungnya kegiatan ekonomi tersebut dengan baik. Dalam hal ini dia mengatakan bahwa negara merupakan pasar yang paling besar bagi dunia dan peradaban yang berarti dia memposisikan negara sebagai wadah untuk kegiatan ekonomi. Adam Smith sendiri, berkaitan dengan hal ini dalam konsep pasar bebasnya tetap menekankan adanya peranan pemerintah. Namun perlu juga dikemukakan sebagai catatan sejarah pemikiran ekonomi Ibnu Khaldun (13321406) mendahului Adam Smith (1723-1790) maupun Karl Max (1818-1883).

Dari uraian tersebut dapatlah ditarik suatu benang merah dari pemikiran ekonomi Ibnu Khaldun yang berupa sebuah konsep ekonomi yang mengidealkan berjalannya aktivias-akitivitas ekonomi masyarakat sesuai dengan hukum atau teori-teori ekonomi. Untuk berjalanya aktivitas-aktivitas ekonomi tersebut, menurut Ibnu Khaldun, rakyat harus diberi ruang (pasar) yang luas dan kondusif dalam setiap usahanya. Di sinilah kemudian berlaku mekanisme pasar yang mensyaratkan tidak boleh adanya kecurangan (kezaliman) dari semua pihak, terutama penguasa (pemerintah). Namun ini bukan berarti berlaku liberalisme ekonomi yang mengabaikan peran pemerintah, dalam konsep ekonominya, Ibnu Khaldun memposisikan pemerintah sebagai penegak keadilan yang harus mengatur dan menjamin berjalannya aktivitas rakyat dengan baik. Hal ini disadari oleh pandangan Ibnu Khaldun bahwa perbedaan hal ihwal penduduk adalah disebabkan perbedaan meraka dalam cara memperoleh penghidupan. Ini berarti menurut Ibnu Khaldun masyarakat tidaklah statis secara ekonomis dimana ini tersirat dari teori yang dikemukakan Ibnu Khaldun tentang peralihan karakter 'umran badawah yang sederhana menjadi 'umran hadarah yang tenggelam dalam kemewahan. Dalam kondisi 'umran hadarah itulah Ibnu Khaldun melihat banyak terjadinya kezaliman dalam bidang ekonomi sebagai implikasi dari karakter pola hidup mereka. Karena keadilan harus ditegakkan untuk menjaga kestabilan akivitas ekonomi dalam perubahan pola hidup tersebut. Namun dalam hal ini Ibnu Khaldun sendiri juga memposisikan penguasa (pemerintah) sebagai bagian dari masyarakat yang mengalami perubahan pola hidup tersebut sehingga ia menyangsikan apakah penguasa akan tetap konsisten dalam menegakkan keadilan dan apakah keadilan yang ditegakkan adalah keadilan yang sesungguhnya. Untuk itu Ibnu Khaldun lalu menjadikan syari'at sebagai dasar penegakkan keadilan dan penguasa adalah pengawas bagi berjalannya keadilan yang didasarkan pada syari'at tersebut. Ini berarti otoritas kebenaran dan keadilan yang sesungguhnya ada pada Allah sebagai Pembuat syari'at tersebut (Syari') dan bukan pada penguasa atau pemerintah.

Dari perspektif etika, konsep ekonominya tersebut Ibnu Khaldun juga mengakui adanya unsur utilitarianisme pada diri manusia yang pada gilirannya membentuk masyarakat untuk menjamin kebutuhan masing-masing individu. Hal Interrelasi ini sekilas tampak mirip dengan pandangan Thomas Hobbes yang menyatakan Antara bahwa masyarakat terbentuk oleh individu-individu yang membuuhkan jaminan keamanan unuk melangsungkan hidupnya. Namun sebenarnya lebih tepat jika 
dipersamakan dengan pandangan Emile Durkheim yang mengakui bahwa masyarakat memang mencakup kontrol atas individu atau oleh kepentingankepentingan mereka, namun itu merupakan proses alamiah menuju kesadaran kolektif yang kemudian menentukan kepercayaan, emosi, dan perilaku individu yang dalam hal ini memiliki kemiripan dengan konsep 'asabiyah atau 'umran badawah dan hadarah yang dikemukakan Ibnu Khaldun. Dapat juga dikatakan bahwa Ibnu Khaldun mengakui pandangan utilitarianisme, namun tetap terbingkai dalam etika relijius, yaitu keadilan yang didasarkan pada syari'at, dalam arti bahwa menurutnya manusia diciptakan Allah lengkap dengan kebutuhan pokok kodratinya yang memang harus dipenuhi serta kesenangan terhadap hal-hal lainnya, tapi harus dengan cara yang tidak bertentangan dengan syari'at sehingga sebetulnya menurut, perspektif etika, konsep tersebut mereflesikan teori perintah Tuhan (divine command theory of moral). Hal ini juga berarti utilitarianisme Ibnu Khaldun berbeda dengan apa yang dikemukakan Jeremy Bentham maupun utilitarianisme kaum Neo-Klasik karena Ibnu Khaldun lebih memaksudkan utilitarianisme sebagai suatu kondisi riil sosio-ekonomi masyarakat dan bukan nilai etis yang melandasi pemikiran ekonominya.

Secara singkat konsep ekonomi Ibnu Khaldun menyatakan bahwa aktivitas ekonomi masyarakat harus dibiarkan berkembang dengan mekanisme pasar tanpa terjadinya kecurangan (kezaliman) yang karena itu keadilan harus ditegakkan oleh pihak penguasa (pemerintah) dan syri'atlah landasannya.

b. Interrelasi antara Etika dan Sistem Ekonomi dalam Konsep Ekonomi Ibnu Khaldun

Pada pembahasan ini, penyusun menyarikan konsep ekonomi Ibnu Khaldun menjadi suatu konsep tentang sistem ekonomi yang berlandaskan syari'at Islam. Yang menjadi fokus tulisan di sini adalah bagaimana interrelasi antara etika dengan sistem ekonomi yang terbangun dari konsep ekonomi Ibnu Khaldun. Interrelasi yang dimaksud di sini adalah sebagaimana telah dikemukakan di atas, adanya hubungan resiprokal antara etika dan sistem ekonomi

Sistem ekonomi adalah seperangkat entitas yang saling berhubungan dan bekerja dalam satu kesatuan untuk meraih sasaran ekonomis suatu masyarakat. Selain itu juga sebagaimana dinyatakan Richard De George bahwa suatu sistem ekonomi akan sangat terkait dengan sistem politik yang akan ikut berperan menentukan pandangan etisnya, bahkan bermoral atau immoralnya suatu sistem ekonomi tersebut, maka konsep ekonomi Ibnu Khaldun sebenarnya lebih menyiratkan suatu konsep sistem ekonomi. Hal ini dapat kita lihat pada nasehat Mubizan yang dinukil Ibnu Khaldun :

Wahai Raja, sesungguhnya kekuasaan (al-Mulk) itu tidak akan mencapai kemuliaannya kecuali dengan adanya syari'at agama dan taat kepada Allah serta tunduk pada perintah dan larangan-Nya. Syari'at tidak akan tegak kecualu dengan kekuasaan. Tidak ada kemuliaan bagi kekuasaan kecuali dengan adanya rakyat (ar-Rijal). Dan manusia tidak akan bertahan tanpa harta (al-Mal). Harta baru akan tercapai kalau diusahakan. Usaha (al-Imarah) tidak akan tercipta kecuali dengan keadilan (al-'Adl). Keadilan adalah timbangan yang tegak ditengah-tengah umat manusia. Tuhan membuatkan pengawas baginya dan pengawas itu adalah raja.

Dari apa yang dikemukakan Ibnu khaldun tersebut terlihat bahwa yang menjadi gagasan ideal dalam konsep ekonomi Ibnu Khaldun adalah ada dan bekerjanya, dalam satu kesatuan, komponen-komponen yang terdiri dari :

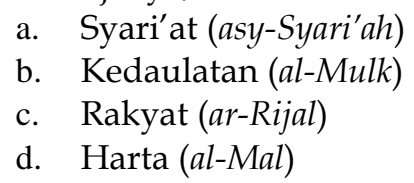


e. Usaha dan aktivitas ekonomi (al-Imarah)

f. Keadilan (al-'Adl)

Saling bekerjanya satu sama lain dari komponen-komponen tersebut dapat kita lihat dalam konteks kajian Ibnu Khaldun tentang al-'umran. Inti dari al'umran yang diajukan Ibnu Khaldun adalah bahwa keberadaan suatu organisasi masyarakat (al-Ijtima' al-Insani) merupakan suatu keharusan bagi manusia. Organisasi masyarakat ini terbentuk melalui solidaritas sosial (assabiyyah) yang dimiliki dan dimunculkan oleh segolongan manusia (al-Rijal) yang untuk mendapatkan sasaran ekonominya (al-Mal) mereka harus melakukan akitivitasaktivitas ekonomi yang mensyaratkan adanya kerja sama satu sama lain. Ketika organisasi masyarakat telah terbentuk, dengan sendirinya manusia memerlukan seorang pemimpin yang memegang kedaulatan (al-Mulk) untuk mengatur hubungan antar individu dalam aktivitas ekonominya sehingga tidak timbul kezaliman.

Dalam pengamatan empirisnya, Ibnu Khaldun mendapati bahwa kedaulatan dan negara merupakan puncak solidaritas sosial ('asabiyyah) sebagaimana masyarakat hadarah (menetap) merupakan puncak dari masyarakat badawah (nomaden). Yang terjadi adalah ketika masih dalam tahap masyarakat badawah, 'asabiyyah masyarakat sangatlah kuat dan sasaran-sasaran ekonominya hanyalah sekedar untuk memenuhi kebutuhan-kebutuhan pokok yang sederhana sehingga kemudian terus berkembang dan terbentuklah masyarakat hadarah dengan kedaulatannya. Kegiatan ekonomipun berkembang dan diikuti oleh perubahan pola hidup masyaraktnya.

Berdasarkan pemikiran tersebutlah Ibnu Khaldun mengemukakan teori tentang jatuh bangunnya peradaban yang karenanya oleh sebagian kalangan sarjana Ibnu Khaldun dipandang sebagai seorang pesimis dan fatalis. Tapi sebetulnya yang dilakukan Ibnu Khaldun adalah suatu pendekatan ilmiah terhadap sejarah yang melibatkan suatu pandangan moral (scientific moral approach to history). Dalam hal ini pandangan moral Ibnu Khaldun didasarkan pada agama (Islam) dimana dia berpendapat bahwa keruntuhan peradaban itu terjadi karena manusia tidak menjaga agamanya dan terikat oleh kebiasaan hidup yang menyeret kepada kemewahan yang menuntut banyak hal, hingga tidak bisa menjaga dunianya. Hal ini senada dengan yang diungkapkan H.A.R Gibb bahwa dalam Muqaddimahnya Ibnu Khaldun menyebutkan tiga dosa sejarah manusia, yaitu kesombongan,kemewahan,dan ketamakan seiring dengan semakin jauhnya mereka dari syariat.

Di sinilah kemudian Ibnu Khaldun berpendapat bahwa syariat agama Islam harus dilibatkan dalam setiap aspek kehidupan, tak terkecuali ekonomi. Sehingga kini akan semakin jelas dimana posisi syariat diantara komponenkomponen sistem ekonomi yang telah disebutkan sebelumnya. Secara skematik bekerjanya keenam komponen yang disebutkan Ibnu Khaldun dapat digambarkan sebagai berikut:

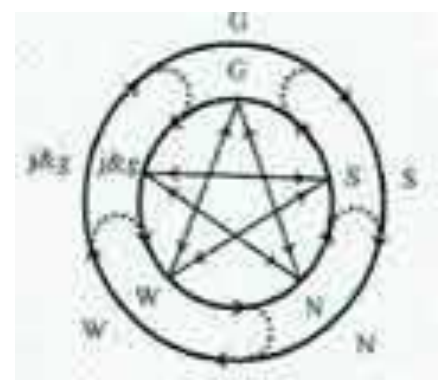

Interrelasi Untuk menjelaskan skema interrelasi tersebut penyusun menggunakan Antara dua format (lingkar) penjelasan, yaitu lingkar eksistensi dan lingkar operasionalisasi. Penjelasannya adalah sebagai berikut: 


\section{Lingkar eksistensi}

Untuk menjelaskan lingkar eksistensi ini perlu dikemukakan terlebih dahulu bahwa yang dimaksud dengan lingkar eksistensi ini adalah bahwa eksistensi atau adanya setiap komponen dalam lingkar tersebut membutuhkan kepada adanya komponen lainnya (dalam skema digambarkan dengan lingkaran besar dengan arah anak panah searah jarum jam). Lebih jelasnya dari apa yang dikemukakan Ibnu Khaldun tentang bekerjanya keenam komponen; syari'at, pemerintah, rakyat, harta, aktivitas ekonomi, keadilan, setiap komponen akan dapat eksis dengan adanya lima komponen lainnya menurut siklus lingkar yang telah digambarkan. Uraian penjelasannya dapat dimulai dari syari'at, menurut Ibnu Khaldun syari'at (asy-Syari'ah) akan dapat ditegakkan melalui sang pemegang kedaulatan (al-Mulk), kedaulatan hanya akan ada bila telah terbentuk suatu komunitas atau peradaban (al-'umran) yang dibangun oleh rakyat (al-Rijal), rakyat akan dapat bertahan dan berkembang dalam hidupnya hanya bila ada harta (al-Mal) dengan segala macam bentuknya, harta hanyaakan diperoleh melalui usaha atau aktivitas ekonomi ( $\left.a l^{\prime}{ }^{\prime} A d l\right)$ yang mengatur jalannya aktivitas tersebut, keadilan ini akan betul-betul merupakan keadilan bila didasarkan pada syari'at dimana yang menjadi pengawas atau penegaknya adalah sang pemegang kedaulatan sehingga ini juga menunjukkan bahwa suatu sistem ekonomi membutuhkan adanya syari'at. Untuk lebih menegaskan lagi lingkar eksistensi tersebut disini diuraikan lebih terperinci lagi interrelasi tersebut melalui penjelasan berikut :

a. Syari'at dan pemerintah

Pemerintahan (al-khilafah) yang didasarkan pada agama, menurut Ibnu Khaldun, sangat berguna untuk kehidupan di dunia maupun di akhirat kelak sebab manusia tidak diciptakan untuk di dunia saja, tapi justru sebaliknya, untuk agama yang akan membawa mereka kepada kebahagiaan hidup di akhirat nantinya. Pandangannya tersebut mengindikasikan bahwa menurutnya syari'at adalah sesuatu yang harus ditegakkan dan dijalankan oleh manusia. Dalam aplikasinya, syari'at ini akan dapat dengan efektif ditegakkan melalui pemerintah atau sang pemegang kedaulatan karena sang pemegang kedaulatan akan diikuti oleh orang-orang yang ada di bawahnya (al-Rijal) yang memberikan dukungan solidaritas social kepada kedaulatan tersebut. Tetapi ini bukan berarti sang pemegang kedaulatan atau pemerintah tersebut merupakan pengada dari syari'at, melainkan sebagai perantara yang sekali lagi' efektif dalam pengimplementasian syari'at.

b. Pemerintah dan rakyat

Adanya pemerintah berarti menunjukkan adanya rakyat. Sebagaimana telah dikemukakan Ibnu Khaldun dalam pembahasan mengenai al-'umranalbasyari, suatu organisasi kemasyarakatan terbentuk karena tiap-tiap individusaling membutuhkan dan ketika telah terbentuk suatu komunitas, diperlukan seorang pemimpin untuk mengatur aktvitas dalam komunitas tersebut. Pemimpin tersebut dipilih berdasarkan 'asabiyyah rakyat terhadapnya. Jika 'asabiyyah rakyat terhadapnya hilang, maka jatuhlah pemmpin tersebut.

c. Rakyat dan harta

Rakyat dalam suatu peradaban terbentuk karena tiap-tiap individu saling membutuhkan, terutama terkait dengan masalah pemenuhan kebutuhan hidup. Hal ini telah dijelaskan oleh Ibnu Khaldun bahwa menurut kodratnya manusia diciptakan Allah dengan kondisi membutuhkan makanan. Selain makanan, manusia membutuhkan berbagai barang yang lainnya yang kesemuanya adalah bagian dari harta dan tanpa itu mereka tidak akan dapat bertahan hidup.

d. Harta dan aktivitas ekonomi

Untuk mendapatkan harta atau kebutuhan hidupnya, setiap orang harus berusaha dengan melakukan aktivitas ekonomi dalam berbagai bentuknya.

\section{Abdul \\ Salam}


e. Aktivitas ekonomi dan keadilan

Aktivitas ekonomi akan berjalan dan berkembang dalam konteks peradaban yang juga mengalami perkembangan pola hidup yang puncaknya ada pada peradaban menetap ('umran hadarah). Pada tahap, menurut Ibnu Khaldun, masyarakat berada dalam pola hidup yang rentan dihinggapi berbagai bentuk kezaliman, terutama terkait dengan masalah ekonomi. Dalam pada ini haruslah ditegakkan keadilan sehingga aktivitas ekonomi akan berjalan dengan baik, karena jika tidak, kezaliman akan merajalela hingga aktivitas ekonomi menurun karena sulit mendapatkan keuntungan dan akhirnya betul-betul terhenti. Jika ini terjadi peradaban akan runtuh karena rakyat tidak dapat bertahan hidup atau meninggalkan peradaban tersebut.

f. Keadilan dan syari'at

Telah disebutkan bahwa kezaliman menurut Ibnu Khaldun adalah segala bentuk tindakan yang bertentangan dengan syari'at. Ini berarti keadilan sebagai lawan dari kezaliman haruslah didasarkan pada syari'at. Selain itu dengan mendasarkan keadilan pada syari'at, kebenaran dari keadilan itu akan terjamin dan konsistensi keadilan tersebut akan terjaga karena landasannya adalah kebenaran Ilahi. Hal ini terkait dengan pandangan Ibnu Khaldun yang memandang pemerintah atau pemegang kedaulatan sebagai bagian dari masyarakat yang juga terimbas perubahan pola hidup sehingga dengan didasarkan pada syari'ah konsistensi keadilannya terjaga dan patokannya jelas karena otoritas kebenarannya ada pada Allah. Di sinilah letak etika dalam sistem ekonomi yang terbangun dari konsep ekonomi Ibnu Khaldun, yaitu keadilan yang didasarkan pada syari'at.

Secara garis besar, lingkar eksistensi tersebut menunjukkan bahwa suatu peradaban dengan sistem ekonominya dapat terus berlangsung dengan baik dengan ditegakkannya keadilan yang disandarkan pada syari'at sementara itu keadilan yang didasarkan pada syari'at dapat ditegakkan dengan efektif dalam suatu peradaban yang terbangun dengan sistem ekonominya. Selanjutnya, uaraian tentang lingkar eksistensi tersebut tidak terlepas dari uraian tentang lingkar operasionalisasi berikut.

\section{Lingkar operasionalisasi}

Yang dimaksudkan dengan lingkar operasionalisasi di sini adalah bekerjanya lingkar eksistensi yang telah disebutkan sesuai siklus yang digambarkan pada skema (lingkaran kecil dengan arah mata panah yang berlawanan arah dengan jarum jam). Jadi, lingkar operasionalisasi ini sekedar menjelaskan bekerjanya lingkar eksistensi.

Melalui lingkar eksistensi ini dapat dijelaskan bahwa pemerintah berpegang pada syari'at. Selanjutnya peraturan dibuat berdasarkan ajaran syari'at untuk menegakkan keadilan. Dengan tegaknya keadilan yang sesungguhnya (yang didasarkan pada syari'at), aktivitas ekonomi akan berjalan dengan baik dan terpelihara dimana perkembangan pola hidup masyarakat juga akan terpengaruhi oleh ajaran syari'at. Aktivitas ekonomi yang berjalan dengan baik akan menghasilkan barang-barang dan kebutuhan rakyat yang mencukupi, bahkan melimpah. Dengan terpenuhinya kebutuhan hidup, rakyat akan dapat bertahan dan melangsungkan kehidupannya dengan baik sehingga keutuhan peradaban terjaga. Rakyat yang hidup makmur selanjutnya akan memberikan dukungan ('asabiyyah) yang kuat pada pemegang kedaulatan hingga kembali lagi, pemerintahan yang kuat akan dapat dengan efektif menegakkan syari'at.

Dalam lingkar operasionalisasi ini yang perlu digaris bawahi adalah tentang aktivitas ekonomi yang diatur dengan keadilan yang didasarkan pada

Interrelasi Antara syari'at. Aktivitas ekonomi yang diatur oleh keadilan didasarkan pada syari'at ini berimplikasi pada harus ditanamkan dan ditegakkannya di dalam aktivitas tersebut prinsip-prinsip sistem ekonomi Islam yang meliputi landasan aqidah, 
moral dan yuridis serta sendi-sendi dari sistem ekonomi Islam. Sehingga pada gilirannya hal ini juga akan menuntut teraplikasinya berbagai institusi ekonomi yang ada pada ajaran syari'at seperti zakat, mudarabah musyarakah, murabahah, pelarangan riba, konsep kepemilikan harta, berbagai hukum jual beli dan sebagainya. Semua ini secara konseptual memungkinkan untuk diformat dalam suatu bentuk sistem ekonomi yang kemudian dapat disebut sistem ekonomi Islam.

Dari uraian tersebut maka jelaslah bahwa syari'at disini -diantaranyaberfungsi sebagai doktrin etis yang harus diimplementasikan oleh pemerintah atau pemegang kedaulatan (al-Mulk) dalam sistem ekonominya melalui penegakkan keadialn yang didasarkan kepada syari'at agama. Tampa syari'at suatu peradaban dengan sistem ekonominya akan terseret ke dalam hukum bangun jatuhnya suatu peradaban sebagaimana yang dikemukakan Ibnu Khaldun. Sehingga tampak disini bahwa syari'at, sebagai referansi penegakkan keadilan, oleh Ibnu Khaldun dipandang sebagai suatu komponen yang memang harus ada (built in) dalam suatu sistem ekonomi. Perlunya penegakkan syari'at dalam suatu peradaban ini terkait juga dengan perkataan Ibnu Khaldun berikut ini :

Semangat agama bisa meredakan pertentangan dan iri hati yang dirasakan oleh satu anggota terhadap anggota lainnya dan menuntun mereka ke arah kebenaran, maka tak ada sesuatupun yang menghalangi mereka, sebab pandangan mereka sama dan tujuannya pun serupa dan satu, yang untuk itu mereka bersedia mati berjuang.

Interrelasi yang terjadi antara syariat sebagai landasan etiak dengan sistem ekonomi Ibnu Khaldun adalah syari'at yang akan menjadi standar etis bagi pandangan dan perilaku ekonomi masyarakat dalam suatu sistem ekonomi melalui penegakkan keadilan yang merupakan komponen moral terpenting dalam sistem ekonomi dimana kebenaran syari'ah bersifat universal dan dapat menyatukan pandangan dan tujuan setiap pihak karena kekuatan otoratifnya berasal dari Allah, sehingga keberadaan dan kesejahteraan suatu peradaban ('umran) dapat terjaga, sementara sistem ekonomi yang terbentuk oleh suatu komunitas manusia dan melingkupinya akan menjadi sarana sekaligus wadah yang efektif bagi tegaknya keadilan ekonomi yang didasarkan syari'at dimana keadaan ekonomi suatu masyarakat yang makmur hingga mencapai suatu bentuk peradaban ('umran) sangat kondusif bagi upaya penegakan suatu keadilan. Interrelasi ini merupakan refleksi dari pemikiran Ibnu Khaldun yang secara singkat dapat dijelaskan bahwa suatu 'umran bila tidak dijaga oleh syari'at pada gilirannya akan muncul di dalamnya berbagai penyimpangan perilaku ekonomi berupa berbagai bentuk kezaliman yang dilakukan terutama oleh pemerintah maupun rakyat sendiri hingga menurunkan aktivitas ekonomi rakyat secara keseluruhan yang kemudian menyebabkan pudarnya 'asabiyyah rakyat terhadap pemerintah yang pada kondisi itu keadilan sulit untuk dapat ditegakkan karena tidak ada lagi kepercayaan rakyat pada pemerintah dan setiap orang mulai meninggalkan wilayah tersebut, dan untuk mencari penghidupan yang lebih baik di tempat lain hingga runtuhlah peradaban yang telah terbentuk. Model sistem ekonomi yang terbangun dari konsep ekonomi Ibnu Khaldun tersebut merupakan sebuah model umum dimana pola interrelasi antara etika yang dalam hal ini adalah keadilan yang didasarkan pada syari'at Islam dan sistem ekonomi dari konsep ekonomi tersebut dapat menjadi model bagi pola interrelasi antara etika dan sistem ekonomi menurut Islam

\section{Kesimpulan}

Telah diuraikan secara singkat tentang kesalingterkaitan antara etika dan sistem ekonomi secara umum hingga diperoleh suatu penjelasan tentang interrelasi antara etika dan ekonomi menurut Islam yang didasarkan pada

Abdul
Salam 
pemikiran ekonomi Ibnu Khaldun. Dari uraian tersebut terdapat beberapa kesimpulan yang penyusun kemukakan sebagai hasil dari tulisan ini, antara lain :

a. Secara historis terdapat keterkaitan yang erat antara etika dan ekonomi dimana pada awalnya ekonomi merupakan bagian dari permasalahan etika. Dalam kondisi tersebut setiap perilaku ekonomi harus mengacu kepada etika sebagai suatu pandangan hidup tentang mana yang benar dan yang salah atau dengan kata lain, ekonomi menjadi pelayan (handmaid) bagi etika. Sementara etika sendiri, sebagai suatu standar benar dan salah, muncul dalam berbagai ragam pemikiran, khususnya para filosof yang kemudian berpengaruh terhadap perbedaan pandangan tentang benar salahnya suatu perilaku ekonomi.

b. Pada kenyataannya masalah ekonomi akan selalu sampai pada titik temunya dengan etika karena yang menjadi subyeknya adalah manusia dalam suatu masyarakat yang tidak bisa terlepas dari suatu pandangan etis dan ketika telah terbentuk sebuah sistem ekonomi maka akan dapat dilihat elemenelemen dasarnya apakah sistem ekonomi tersebut bertentangan atau tidak dengan pandangan etis yang ada. Hal ini berarti bahwa etika memiliki tempat sekaligus ikut mengarahkan kegiatan ekonomi yang ada dalam suatu sistem ekonomi

c. Dalam Islam permasalahan ekonomi mendapatkan perhatian dan pandangan yang positif hingga dalam Islam sendiri terdapat hukum dan konsep institusiinstitusi ekonomi yang sangat memungkinkan terbentuknya suatu sistem ekonomi dimana syari'at Islam menjadi sumber dan ajaran etis bagi kegiatan ekonomi di dalamnya dengan semua landasan aqidah, moral, yuridis dan sendi-sendinya.

d. Pemikiran ekonomi Ibnu Khaldun menampilkan sebuah konsep ekonomi yang multidimensional dengan melibatkan berbagai aspek social dalam konteks pemikirannya tentang al-'umran al-basyari yang menjelaskan jatuh bangunnya suatu peradaban dimana aspek kemorosotan moral sangat berperan di dalamnya. Hal ini terkait dengan pandangan Ibnu Khaldun bahwa masyarakat tidaklah statis dari sisi kehidupan ekonominya, melainkan mengalami perubahan pola hidup. Dalam pada itulah Ibnu Khaldun menempatkan syari'at sebagai sumber etika yang harus ditegakkan oleh sang pemegang kedaulatan dalam usahanya menegakkan keadilan di tengahtengah aktivitas ekonomi rakyatnya yang terus mengalami perubahan dan perkembangan.

e. Konsep ekonomi Ibnu Khaldun menyiratkan sebuah sistem ekonomi yang menuntut bekerjanya lima komponen, yaitu syari'at, pemerintah, rakyat, harta, aktivitas ekonomi dan keadilan dalam satu kesatuan. Dari sinilah terjalinlah suatu interrelasi antara syari'at sebagai sumber etika dalam Islam dengan suatu sistem ekonomi dimana syari'at akan menjadi landasan keadilan bagi sistem ekonomi yang ada pada suatu komunitas atau peradaban, sementara sistem ekonomi yang ada dengan komunitas atau peradaban yang melingkupinya yang akan menjadi sarana sekaligus wadah yang efektif bagi tegaknya syari'at Islam.

Interrelasi

Antara 


\section{DAFTAR PUSTAKA}

Ahmad, Khursid (Ed), 1981, Studies in Islamic Economics, The Islamic Foundation, Leicester

al-Husri, Sati', 1962, Dirasat 'an Muqaddimah Ibnu khaldun, cet. 3, Dar al-Kitab al'Arabi, Mesir

an-Nabhan, Muhammad Faruq, 1984, al-Ittijahu al-Jama'I fi at-Tasyri' al-Iqtishodi alIslami, cet. 2, Mu' assasah ar-Risalah, Beirut

Anwar, Muhammad, 1987, Modelling Interest-Free Economy : A Study In Macroeconomics and Development, International Institute of Islamic Thought, ttp

Campbell, Tom, 2001, Tujuh Teori Sosial, alih bahasa : F. Budi Hardiman, cet. 6, Kanisius, Yogyakarta

Fromm, Erich, 2001, Konsep Manusia Menurut Marx, alih bahasa : Agung Prihantoro, cet. I, Pustaka Pelajar, Yogyakarta

Gove, Philip B. (ed.), 1981, Whebster's Third New International Dictionary of the English Language and Seven Languages Dictionary, jilid I, G. \& C. Merriam Co., USA

Islahi, Abdul Azim, 1996, Economic Concepts of Ibnu Taimiyah, The Islamic Foundation, Leicester

Khaldun , Ibnu, 1979, Kitab al-'Ibar, jilid I Dar al-Fikr, Beirut

-------, 2000, Muqaddimah Ibn Khaldun, alih bahasa Ahmadie Thoha, cet. 2, Pustaka Firdaus, Jakarta

Khudhairi, Zainab, 1979, Filsafat Sejarah Ibn Khaldun, alih bahasa Ahmad Rofi' Utsmani, cet. 1, Pustaka, Bandung

Lumbotaruan, Magdalena dan B. Soewarotoyo, 1992, Ensiklopedi Ekonomi, Bisnis dan Manajemen, jilid I, cet. 1, PT. Cipta Adi Pustaka, Jakarta

Mannan, M. Abdul, 1997, Teori dan Praktek Ekonomi Islam, alih bahasa Nastangin, PT. Dana Bhakti Prima Yasa, Yogyakarta

Naqvi, Syed Nawab Haider, 1993, Etika dan Ilmu Ekonomi (Suatu Sintesis Islami), alih bahasa Husin Anis dan Asep Hikmat, cet. 3, Mizan, Bandung

Rahardjo, M. Dawam, 1990, Etika Ekonomi dan Management, cet. 1, PT. Tiara Wacana, Jakarta

Salim, Peter dan Yenni Salim, 1991, Kamus Bahasa Indonesia Kontemporer, edisi I : Modern English Press, Jakarta

Shaw, Stanford J. dan William R. Polk (ed), 1982, Studies on the Civilization of Islam, cet. 1, Princeton University Press, New Jersey

Shaw, William H., 1999, Social and Personal Ethics, edisi 3, Wadsworth Publishing Company, USA

Siddiqi, Muhammad Nejatullah, 1991, Kegiatan Ekonomi dalam Islam, alih bahasa Anas Sidik, cet. 1, Bumi Aksara, Jakarta

Smith, Adam, t.t., An Inquiry into the Nature and Canses of the Wealth of Nations, The Modern Library, New York

Sumitro, Warkum, 1996, Asas-asas Perbankan Islam dan Lembaga-lembaga Terkait (BMUI dan Takaful) di Indonesia, cet. 1, PT. Raja Grafindo, Jakarta

Suseno, Franz Magnis, 1999, Pemikiran Karl Marx : Dari Sosialisme Utopis ke Perselisihan Revisionis, cet. 2, PT. Gramedia Pustaka Utama, Jakarta

Triyuwono, Iwan, 2000, Organisasi dan Akuntansi Syari'ah, cet. 1, LKiS, Yogyakarta

Weber, Max, 2000, Etika Protestan dan Semangat Kapitalisme, alih bahasa Yusuf Priyasudiarja, cet. 1, Pustaka Promethea, Surabaya 